\title{
Uji Daya Serap Diapers Anti Ruam (Diapers Rash) Modifikasi Sabut Kelapa (Cocosnucifera)
}

\author{
${ }^{1}$ Intan Kusliayana, ${ }^{2}$ Siti Mardiyah \\ Prodi D3 Analis Kesehatan, Fakultas Ilmu Kesehatan, Universitas Muhammadiyah \\ Surabaya \\ sitimardiyahfix2@gmail.com
}

\begin{abstract}
Tanggal

Submit:

18 Juni 2019

Tanggal

Review:

24 Juni 2019

Tanggal

Publish Online:

2 Oktober 2019

The World Health Organization (WHO) reported in 2012 that the prevalence of skin irritation (diaper rash) in infants was quite high at $25 \%$ due to the use of diapers. One of the causes of diaper rash is caused by low diaper absorption. Increased absorption of diaper can be done by increasing the absorbent ability of diapers to absorb baby urine. The natural absorbent that can be modified in baby diapers is coconut fiber. Cellulose content in coconut fiber has the ability to absorb liquid high enough. This potential can be applied to absorb urine and sweat so that it can reduce moisture in baby diapers. Diapers that have high absorption can prevent the occurrence of rashes in infants. This study aims to examine differences in absorbency of diapers. Without coconut fiber and coconut husk modification diapers.

This type of research is experimental. The population and sample of the study were baby diapers with a total sample of 32 which were divided into 2 groups namely baby diapers without coconut fiber and with modification of coconut fiber. Testing for diaper absorption is carried out in a laboratory manner by measuring the volume and time of absorption of fluids given to diapers to the saturation limit (leak). The data analysis technique uses the independent t-test. Based on the results of the independent t-test showed that there were significant differences in the amount of volume and time of absorption of fluids given to bunch diapers and with coconut fiber. Thus it can be concluded that there is a significant influence on the addition of coconut fiber to the absorption of fluid in baby diapers.
\end{abstract}

Keywords: Diapers, Rash, Coconut Fiber.

\section{PENDAHULUAN}

Ruam popok atau dermatitis merupakan masalah yang selalu dialami oleh setiap bayi atau balita. Berdasarkan data yang dikeluarkan oleh Badan Kesehatan Dunia (WHO) pada tahun 2012 prevalensi iritasi kulit (ruam popok) pada bayi cukup tinggi $25 \%$ dari 6.840.507.000 bayi yang lahir di dunia kebanyakan menderita iritasi kulit (ruam popok) akibat penggunaan popok. Angka terbanyak ditemukan pada usia 612 bulan (Ramba, 2015). Insiden ruam popok di Indonesia mencapai 7-35\%, 
yang menimpa bayi laki-laki dan perempuan berusia dibawah tiga tahun, (Budi Arja Sita A, 2009) dalam (Heni Frilarasari, 2016).Penggunaan diapers selama terus menerus berpotensi menyebabkan ruam pada bayi.. Di Indonesia, dari sebuah survey yang dilakukan oleh Putri (2012) didapatkan hasil bahwa secara keseluruhan penggunaan popok sekali pakai hanya berkisar 74\%dan 39\% untuk kota-kota kecil.

Menurut Titi LS, eksim popok yang disebut juga dermatitis popok adalah kelainan kulit yang timbul akibat radang di daerah yang tertutup popok, yaitu dialat kelamin, sekitar dubur, bokong, lipatan paha dan perut bagian bawah. Penyakitini sering terjadi pada bayi dan anak balita yang menggunakan popok, biasanya pada usia kurang dari tiga tahun, paling banyak usia 9-12 bulan (Rukiyah. A \&Yulianti, 2010).

Ruam popok merupakan kelainan peradangan kulit di daerah yang tertutup popok yang paling sering diderita oleh bayi. Dermatitis diapers atau ruam popok adalah gangguan kulit yang timbul akibat radang di daerah yang tertutup popok, yaitu di alat kelamin, sekitar dubur, bokong, lipatan paha, dan perut bagian bawah. biasanya disebabkan iritasi oleh urine dan feses (Rukiyah, A \& Yulianti, 2010).
Ruam popok dapat diakibatkan oleh berbagai faktor, misalmya popok basah atau jarang ganti popok, sensitivitas kulit, dan gesekan. Ruam popok bukan kondisi serius namun jika dibiarkan dapat menjadi kasus yang berat, bisa berubah menjadi kasus infeksi jamur atau bakteri. Ini karena tingkat penyerapan air pada popok rendah. Tidak sedikit yang terjadi baik pada bayi perempuan maupun laki-laki yang di pakaikan popok sejak bayi akhirnya harus menjalani operasi alat kelamin, karena mengalami kesulitan kencing yang disebabkan pengendapan air seni pada diapers yang menimbulkan tumbuhnya jamur dan bakteri serta kurangnya sirkulasi udara pada saat menggunakan diapers. (Ramba, 2015).

Upaya peningkatan daya serapmpopok harus senantiasa dialakukan untuk mengatasi insiden ruam popok pada bayi. Salahsatu cara untuk meningkatkan daya serap popok terhadap urine bayi adalah dengan memodifikasi bahan absorben aktif dalam popok.

Bahan alami yang memiliki kemampuan untuk menyerap air adalah sabut kelapa. Sabut merupakan bagian mesokarp (selimut) yang berupa serat-serat kasar kelapa. Bagian yang berserabut ini merupakan kulit dari buah kelapa 
Sejauh ini sabut kelapa dimanfaatkan dalam aneka industri seperti karpet, keset, sikat,bahan pengisi jok mobil, tali dan lainnya. Penelitian terdahulu yang sudah dilakukan terhadap sabut kelapa terbatas sebagai pewarna, biabsorben, dan campuran pupuk, dan sebagai kerajinan seni.

Komponen dasar sabut kelapa terdiri dari selulosa, hemiselulosa dan lignin. Selulosa merupakan salah satu komponen penyusun dinding sel tumbuhan. Selulosa memiliki material padatan berpori sehingga mampu menyerap bahan-bahan di sekelilingnya.

Selulosa dibagi atas tiga jenis yaitu alfa selulosa, beta selulosa, dan gamma selulosa.

Hasil uji komposisi serat sabut kelapa berdasarkan SNI yang dilakukan Sarana Riset dan Standarisasi dapat dilihat pada tabel 1 berikut :

Tabel 1 Komposisi Serat Sabut Kelapa

\begin{tabular}{|l|l|l|}
\hline \multicolumn{1}{|c|}{$\begin{array}{c}\text { Parameter } \\
\text { Hasil Uji }\end{array}$} & $\begin{array}{c}\text { Kompo- } \\
\text { sisi (\%) }\end{array}$ & $\begin{array}{c}\text { Metode } \\
\text { Uji }\end{array}$ \\
\hline Kadar Abu & 2.02 & $\begin{array}{l}\text { SNI 14- } \\
1031- \\
1989\end{array}$ \\
\hline $\begin{array}{l}\text { Kadar Lignin } \\
\text { (Metode } \\
\text { Klason) }\end{array}$ & 31.48 & $\begin{array}{l}\text { SNI 14- } \\
0492- \\
1990\end{array}$ \\
\hline Kadar Sari & 3.41 & $\begin{array}{l}\text { SNI 14- } \\
1032- \\
1989\end{array}$ \\
\hline
\end{tabular}

\begin{tabular}{|l|l|l|}
\hline $\begin{array}{l}\text { Kadar Alfa } \\
\text { Selulosa }\end{array}$ & 32.64 & $\begin{array}{l}\text { SNI 14- } \\
\text { 0444- } \\
1989\end{array}$ \\
\hline $\begin{array}{l}\text { Kadar Total } \\
\text { Selulosa }\end{array}$ & 55.34 & $\begin{array}{l}\text { Metoda } \\
\text { Internal } \\
\text { BBPK }\end{array}$ \\
\hline $\begin{array}{l}\text { Kadar } \\
\text { Pentosan } \\
\text { sebagai } \\
\text { Hemiselulosa }\end{array}$ & 22.70 & $\begin{array}{l}\text { SNI 01- } \\
1561- \\
1989\end{array}$ \\
\hline $\begin{array}{l}\text { Kelarutan } \\
\text { dalam NaOH 1 } \\
\%\end{array}$ & 20.48 & $\begin{array}{l}\text { SNI 19- } \\
1938- \\
1990\end{array}$ \\
\hline
\end{tabular}

Sumber : Sunario, 2008 dalam (Laboratorium Balai Besar Pulp dan Kertas)

Potensi selulosa memiliki kemampuan penyerapan tinggi terhadap zat cair dapt diaplikasi untuk menyerap urine dan keringat sehingga dapat mengurangi kelembaban didalam diapers. (Mauliyah Shofiyah Hanum, 2015).

Potensi selulosa pada sabut kelapa inilah yang menjadi landasan untuk diaplikasikan sebagai bahan absorben pada diapers untuk memingkatkan daya serap urine bayi. Dengan demikian hal ini dapat meminimalisir terjadinya ruam pada kulit bayi. maka peneliti melakukan penelitian tentang sabut kelapa yang akan digunakan sebagai bahan dari pembuatan diapers sabut kelapa anti ruam. Penelitian ini bertujuan untuk menguji perbedaan daya serap popok .tanpa sabut kelapa dan popok modifikasi sabut kelapa. 


\section{METODE PENELITIAN}

Jenis penelitian ini bersifat eksperimental untuk memepelajari daya serap popok modifikasi sabut kelapa dibandingkan dengan popok tanpa sabut kepala.

Populasi dan sampel penelitian adalah popok bayi (diapers) dengan junlah total sampel 32 popok, yang dibagi menjadi 2 kelompok yakni popok tnpa sabut kelapa dan popok dengan sabut kelapa.

Variabel Penelitian terdiri atas variabel bebas dan variabel terikan. Variabel bebas adalah jenis opok, dalam hal ini dibedakan menjadi Tanpa sabut kelapa dan dengan sabut kelapa. Sedangkan variabel terikat adalah daya serap popok yang diukur dengan 2 kategori yakni 1).Jumlah voume air yang mampu diserap popok hingga Jenuh (bocor) dinyatakan dengan satuan $\mathrm{mL}$; 2) Kecepatan waktu serap popok menyerap air hingga jenuh (bocor) dinyatakan dalam satuan detik.

Bahan yang digunakan dalam penelitian ini antara lain : sabut kelapa, diapers, alkohol $70 \%$, gel poliponik Bahan baku utama yang digunakan adalah dipers dengan modifikasi sabut kelapa. Sabut kelapa diperoleh dari pedagang kelapa yang ada dipasar-pasar tradisional ataupun dari pedagang rumahan sabut kelapa di desa-desa, selain murah juga sangat mudah didapatkan.

Sedangkan alat yang digunakan dalam uji laboratorik daya serap popok antara lain

Neraca analitik, oven, mortar, beaker glass, erlenmeyer, gelas ukur, petridist, spatula.

Pengujuran daya serap popok pada kedua kelompok diats dilakukan dengan langkah-langkah berikut ini. Sampel popok yang sudah diambil secara random dibagi menjadi 2 kelompok yakni kelompok tanpa serabut dan dengan modifikasi sabut kelapa. Langkah berikutnya adalah penyiapan serbuk sabut kelapa dilakukan dengan menumbuk sejumlah sabut kelapa hingga menjadi serbuk. Serbuk sabuk kelapa selanjutnya disterilisasi dengan menambahkan Larutan alkohol 70\% ke dalam serbuk sabut kelapa. Serbuk didiaduk dan didiamkan beberapa saat, kemudian dioven dengan suhu $90^{\circ} \mathrm{C}$ selama 15 menit atau hingga benarbenar kering. Setelah kering, sabut kelapa dikeluarkan dari oven dan ditunggu dingin pada suhu ruang.

Langkah berikutnya adalah menambahkan serbuk sabut kelapa ke dalam popok pada kelompok modifikasi sabut kelapa. Penambahan jumlah serbuk sabut dibuat sama pada tiap 
sampel popok. Penambahan sabut kelapa dilakukan dengan memasukkan serbuk sabut kelapa dan bahan-bahan lain pada dipers modifikasi. Bagian diapers yang digunakan untuk memasukkan serbuk kelapa ditutup dengan cara dijahit, dilem dan ditutup dengan plester roll.

Setelah proses modifikasi selesai, kemudian dilakukan uji daya serap Air. Pengukuran daya serap popok dilakukan dengan 2 kategori yakni 1).mengukur jumlah volume cairan yang diserap popok hingga jenuh (bocor) yang dinyatakan dengan mililiter (ml) dan 2). Mengukur kecepatan penyerapan cairan oleh popok yang dinyatakan dalam satuan (detik).

Data hasil pengukuran daya serap popok berupa jumlah volume cairan dan waktu penyerapan, selanjutnya ditabulasikan dan dilakukan analisis data dengan uji statistik menggunakan uji tbebas untuk mengetahui perbandingan daya serap popok tandan dan dengan modifikasi sabut kelapa.

\section{HASIL DAN PEMBAHASAN}

Hasil uji laboratorik daya serap popok berdasarkan jumlah cairan yang mampu diserapoleh popok tanpa dan dengan modifikasi sabut kelapa hingga jenuh (bocor) disajikan ada tabel 2 berikut ini.
Tabel 2 : Daya serap popok berdasarkan volume cairan yang diserap

\begin{tabular}{|c|c|c|}
\hline \multirow{2}{*}{ sampel } & \multicolumn{2}{|c|}{$\begin{array}{c}\text { Daya Serap Popok } \\
\text { berdasarkan jumlah } \\
\text { volume cairan yang } \\
\text { diserap (mL) }\end{array}$} \\
\cline { 2 - 3 } & $\begin{array}{c}\text { Tanpa } \\
\text { Sabut } \\
\text { Kelapa }\end{array}$ & $\begin{array}{c}\text { Dengan } \\
\text { Sabut } \\
\text { Kelapa }\end{array}$ \\
\hline P1 & 700 & 850 \\
\hline P2 & 750 & 980 \\
\hline P3 & 700 & 900 \\
\hline P4 & 800 & 900 \\
\hline P5 & 750 & 900 \\
\hline P6 & 820 & 980 \\
\hline P7 & 850 & 960 \\
\hline P8 & 700 & 850 \\
\hline P9 & 700 & 850 \\
\hline P10 & 800 & 980 \\
\hline P11 & 700 & 850 \\
\hline P12 & 700 & 850 \\
\hline P13 & 750 & 980 \\
\hline P14 & 700 & 850 \\
\hline P15 & 700 & 850 \\
\hline P16 & 700 & 900 \\
\hline Jumlah & $\mathbf{1 1 8 2 0}$ & $\mathbf{1 4 4 3 0}$ \\
\hline Rata-rata & $\mathbf{7 3 9}$ & $\mathbf{9 0 2}$ \\
\hline & & \\
\hline & & \multicolumn{1}{|c|}{} \\
\hline & & 950 \\
\hline
\end{tabular}

Sedangkan Hasil uji laboratorik daya serap popok berdasarkan waktu yang dibutuhkan oleh popok tanpa dan dengan modifkasi sabut kelapa untuk menyerap cairan hingga jenuh (bocor) disajikan ada tabel 3 berikut ini. 
Tabel 3 : Daya serap popok berdasarkan waktu penyerapan

\begin{tabular}{|c|c|c|}
\hline \multirow{2}{*}{ sampel } & \multicolumn{2}{|c|}{$\begin{array}{c}\text { Daya Serap Popok } \\
\text { berdasarkan } \\
\text { Kecepatan waktu } \\
\text { penyerapan (detik) }\end{array}$} \\
\cline { 2 - 3 } & $\begin{array}{c}\text { Tanpa } \\
\text { Sabut } \\
\text { Kelapa }\end{array}$ & $\begin{array}{c}\text { Dengan } \\
\text { Sabut } \\
\text { Kelapa }\end{array}$ \\
\hline P1 & 58 & 18 \\
\hline P2 & 40 & 22 \\
\hline P3 & 36 & 19 \\
\hline P4 & 38 & 19 \\
\hline P5 & 42 & 20 \\
\hline P6 & 40 & 18 \\
\hline P7 & 38 & 19 \\
\hline P8 & 48 & 20 \\
\hline P9 & 46 & 21 \\
\hline P10 & 38 & 20 \\
\hline P11 & 40 & 17 \\
\hline P12 & 40 & 18 \\
\hline P13 & 44 & 22 \\
\hline P14 & 32 & 24 \\
\hline P15 & 32 & 20 \\
\hline P16 & 36 & 22 \\
\hline Jumlah & $\mathbf{6 4 8}$ & $\mathbf{3 1 9}$ \\
\hline Rata-rata & $\mathbf{4 0 , 5}$ & $\mathbf{1 9 , 9}$ \\
\hline & & \\
\hline
\end{tabular}

Berdasarkan uji laboratorik terhadap daya serap popok berdsarkan jumlah volume cairan yang disearp dan waktu penyerapan yang disajikan pada tabel 2 dan tabel 3 menunjukkan perbedaan nilai rata2 daya serap yang cukup besar. Nilai rata-rata jumlah cairan yang diserap popok tanpa sabut sebesar $739 \mathrm{~mL}$, sedangkan popok dengan sabut kelapa $902 \mathrm{~mL}$. Sedangkan nilai rata-rata waktu penyerapan popok tanpa sabut kelapa 40,5 detik dan popok dengan sabut kelapa 19,9 detik.

Data pada tabel 3 dapat digambarkan dalam bentuk diagaram batang untuk memperjelas penggambaran perbedaan daya serap popok tandan dan dengan sabut kelapa. Gambaran perbandingan daya serap popok berdasarkan jumlah volume cairan yang diserap sebagaimana disajikan dalam Gambar 1 berikut ini

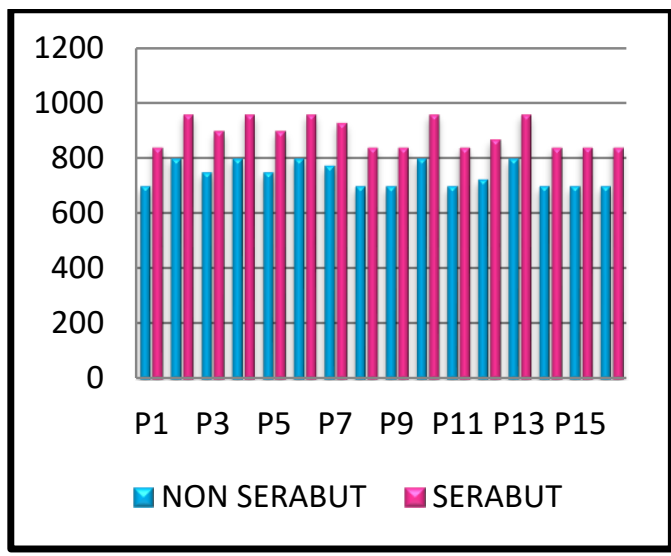

Gambar 1. Daya serap popok berdasarkan volume cairan yang terserap $(\mathbf{m L})$

Sedangkan Diagram batang untuk memberikan gambaran perbandingan daya serap popok tanpa dan dengan sabut kelapa berdasarkan waktu penyerapan popok sebagaimana disajikan dalam Gambar 2 berikut ini 


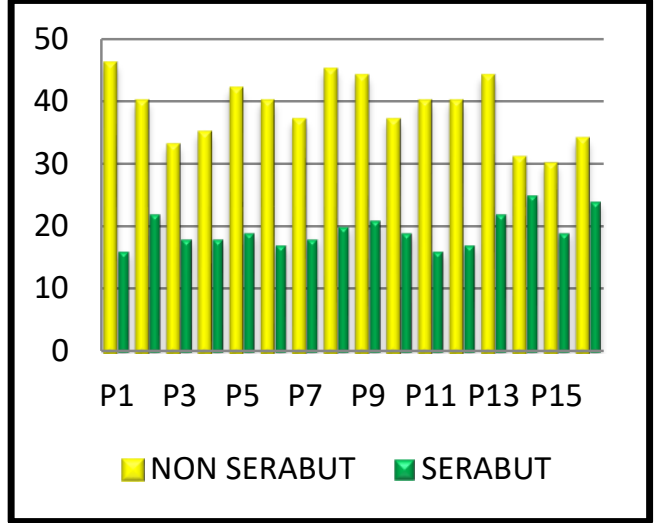

\section{Gambar 2 Daya serap popok berdasarkan volume cairan yang terserap (detik)}

Berdasarkan nilai rata-rata volume cairan yang diserap oleh popon tanapa dan dengan sabut kelapa masing $739 \mathrm{~mL}$ dan $902 \mathrm{~mL}$, menunjukkan perbedaan yang cukup besar. Perbedaan nilai rata-rata ini menunjukkan bahwa popok sabut kelapa mampu menampung cairan dengan volume yang lebih besar dibandingkan dengan popok tanpa sabut kelapa.

Demikian pula berdasarkan waktu serap kedua popok tanda dan dengan sabut kelapa masing-masing 40,5 detik dan 19,9 detik menunjukkan adanya perbedaan yang cukup besar. Nilai ratarata ini bermakna bahwa popok dengan sabut kelapa mampu menyerap air lebih cepat dibandingkan dengan popok tanpa sabut kelapa.

Hasil uji t bebas terhadap volume penyerapan jenuh dan kecepatan penyerapan pada popok serabut kelapa dan tanpa sabut kelapa menujukkan nilai signifikansi yaitu $0,00 \quad(<0,05)$ artinya ada perbedaan daya serap antara memakai serabut dan tanpa modifikasi serabut kelapa.

Hasil Uji $t$ ini semakin memperkuat bahwa perbedaan rata-rata penyerapan popok tanpa dan dengan sabut kelapa baik yang diukur berdasarkanjumlah volume cairan ataupun waktu penyerapan menunjukkan perbedaan yang bermakna., yang menunjukkan bahawa popok sabut kelapa lebih optimal untuk menyerap air.

Daya serap merupakan kemampuan dalam menyerap zat cair. Kemampuan popok sabut kelapa meningkatkan penyerapan disebabkan karena adanya selulosa yang terkandung dalam sabut kelapa.

Kandungan selulosa dalam sabut kelapa mencapai $55.34 \%$. Modifikasi sabut kelapa dalam dipers dapat meningkatkan penyerapan zat cair hingga 20\%. Sehingga pemakaian diapers modifikasi pada bayi dapat meminimalisir tingkat ruam yang terjadi karena cairanan urine terserap lebih banyak dan lebih cepat sehingga tidak gampang jenuh, dan popok lebih tahan lama dalam kondisi kering. Hal ini akan mengurangi kelembabapan pada bayi sebagai sumber terjadinya ruam. 
Ruam terjadi karena tingkat penyerapan diapers/popok yang rendah. Penyerapan popok yang rendah dapat meningkatkan kelembababn yang bisa memicu tumbunya kuman dan bakteri yang dapat menimbulkan iritasi pada kulit.

Berdasarkan analisis ini, popok bayi modifikasi sabut kelapa dapat dipertimbangkan sebagai popok yang bisa mengatasi anti ruam pada bayi, karena memiliki daya serap lebih tinggi dibandingkan dengan popok biasa.

\section{KESIMPULAN}

Berdasarkan hasil penelitian Uji Daya Serap Diapers Anti Ruam (Diapers Rash) Modifikasi Sabut Kelapa (Cocosnucifera) ini dapat disimpulkan sebagai berikut :

1. Ada perbedaan jumlah volume cairan yang mampu diserap popok tanpa sabut kelapa dan popok modifikasi sabut kelapa

2. Ada perbedaan waktu penyerapan popok tanpa sabut kelapa dan popok modifikasi sabut kelapa

3. Ada perbedaan daya serap popok tanpa sabut kelapa dengan popok modifikasi sabut kelapa.

\section{DAFTAR PUSTAKA}

Amin, Sarmidi dan Kurniadhi Prabandono.2014.Coco

Preneurship.Yogyakarta: Lily Publisher.

Budiarja, Siti Aisah. 2009. Perawatan Kulit Pada Bayi Dan Balita.Jakarta : FKUI Press.

Diaper Rash.2013. http://www.nlm.nih.gov/medlineplus. Diakses pada tanggal : 25 September 2017 pukul 10.25 WIB

Diena. 2009. http://digilib.unimus.ac.id/files/disk1/11 1/jtptunimus-gdl-ifachozina-55173babii.pdf. Diakses pada tanggal 25 September 2017 pukul 9.49 WIB

Diena, 2009. "Popok Modern bisa Sebabkan Mandul. Diakses pada tanggal 29 September 2017. http//Dienaanakbunda.net/new/.

Koolman J, Rohm KH. 2000. Atlas Berwarna dan Teks Bioimia. Wanandi S, penerjemah. Jakarta: Hipotesis. Terjemahan dari: Color Atlas of Biochemistry.

Mahmud Zainal, Yulius Ferry. 2005. Prospek Pengolahan Hasil Samping Buah Kelapa. Bogor: Perspektiv.

Maryunani, Anik. 2010. Ilmu Kesehatan Anak Dalam Kebidanan, Jakarta: Trans Info Media.

Ramba, Hardin La. 2015. Kejadian Iritasi Kulit (Ruam Popok) Pada Bayi Usia 0-12 Bulan. Journal of Pediatric Nursing Vol. 1(2) STIKES Nani Hasanuddin Makassar. 
Rukiyah, A.Y, Yulianti, L.2010. Asuhan Neonatus Bayi dan Anak Balita. Jakarta: CV. Trans Info Medika.

Samosir, Y.1992. Asal usul Penyebaran Kelapa, dalam Kelapa (Cocos nucifera, L), Asosiasi Litbangbun, Puslitbun Marihat_Bandar Kuala Pematang Siantar.

Soepardan, Suryani. 2001. Panduan Perawatan Bayi Sakit. Jakarta: Puspa Swara.

http://www.plantamor.com/index. php?plant $=365$

http://sharingdisana.com/2014/06/ 02/bahaya-penggunaan-popok-padabayi-secara-terus-menerus/ Diakses pada : 27 September 2017

Hws. 2015.kegunaan unik kelapa. https://www.vemale.com/ragam/840005-kegunaan-unik-kelapa-yang-mungkinbelum-anda-tahu.html Diakses pada : 28 september 2017 